\title{
OPERATIONAL DEGRADATION OF ENGINE OIL IN AGRICULTURAL TECHNOLOGY
}

\author{
Petr DOSTÁL, Jakub ROZLIVKA*, Vojtěch KUMBÁR \\ Mendel University in Brno, Czech Republic
}

\begin{abstract}
Proposed paper is focused on description and observation of operational degradation of engine oil in agricultural technology. Engine oil is one of the most important liquids used in combustion engines. Correct function of any machine is based on the appropriate selection of lubricants; moreover, it is also important to care for the entire lubrication system. Determining the condition of the oil used in operational conditions is very important for potential further oil use. Previously, engine oil had to be changed after expiration of legally valid intervals regardless of its actual performance parameters. However, its usage may be extended if engine oil parameters meet the legal requirements. This can be achieved by removing engine oil samples from machines on a regular basis. By examining the samples taken, it is possible to determine the actual oil state. In such manner, it is possible to prolong interchange periods and save both the financial resources and environment.
\end{abstract}

Keywords: engine oil; oil degradation; metals in engine; viscosity; density

Tractor fluids are used for lubrication of transmissions, final drives, wet brakes, etc. (Kučera and Aleš, 2017). However, these fluids are primarily exposed to heat, chemical and mechanical stress during operation. These kinds of lubricating oil loads are the main cause of its "aging" and contamination. Oil gradually loses its lubricating ability. These penetrate the crankcase of gases between the piston and cylinder, causing oil oxidation. Acids can also be produced. Furthermore, oil is also contaminated by carbon, dust and metal particles. This is due to oil contamination by particles in the combustion chamber and their subsequent combustion (Hromádko, 2011; Kosiba et al., 2016). Impurities and condensing water deteriorate the oil circulation in lubrication system. The heavier components of gasoline, especially in cold engine, dilute the lubricating film on the cylinder wall. Considering the diesel motors, lubricating oil is also contaminated by soot. Contaminated fluid poses a risk to the machine in terms of wear and failure (Tulík et al., 2013). Contamination is very dangerous since it accelerates degradation and oxidation processes in fluids (Tkáč et al., 2017).

Mechanical impurities (dust, carbon, metal particles) can be removed using a suitable cleaner. However, oil degradation caused by chemical influences (oxidation) remains. Application of cleaners can postpone the necessity to change the lubricating oil, but regular replacement of oil is necessary to maintain acceptable engine life. Terms for oil exchange are fixedly determined by manufacturer on the basis of travelled distance or engine operating time.

The main aim of this work is to find out if the oil replacement service interval in agricultural machines can be extended if oil samples are regularly taken for subsequent analysis of important parameters determining whether oils are still suitable for further operation. Motor oil samples were taken from the Zetor 5211 tractor. This tractor is used as a training vehicle of driving school at the Secondary school of Crafts and Services in Velké Meziřičí. Therefore, this machine is operated mostly on road traffic. Tractors of this type are used as training vehicles in driving schools even today. Although it is an older machine, it is represented in great numbers in the Czech Republic. In general, it can be said that Zetor tractors are still the most utilized tractors in the Czech Republic. Motors in the Zetor 5211 tractor are used also in UNC loaders and DESTA lift trucks. Technical parameters of the Zetor 5211: power max - 32 kW/43 hp; displacement - 2,697 ccm/2.7 L/165 cin; cylinders - 3; cooling - water-cooling; fuel capacity - $55 \mathrm{~L} / 15$ gal.

\section{Material and methods}

Madit M7 ADS III engine oil was used for the measurement purposes. This oil is universalyear-long engine oil and suitable especially for heavy freight, ship and rail transportation according to the producer's recommendations. The oil is suitable for over-filled, as well non-over-filled diesel engines. It can be used in agricultural, forestry and earth machines. This oil is used in a mixed fleet and its technical parameters are shown in Table 1.

This oil was taken from the Zetor tractor. Sampling interval was set to be 50 hours of operation. The first oil sample taking was performed after oil replacement and after a short machine operation. Individual samplings are shown in the following table (Table 2). Furthermore, a sample of new unused oil was taken in order to compare it with the 
Table 1 Technical parameters of tested oil

\begin{tabular}{|l||c|c|c|c|c|}
\hline Oil type & Viscosity class & Efficiency class & Kinematic viscosity $\left(\mathbf{m m}^{\mathbf{2}} \cdot \mathbf{s}^{-\mathbf{1}}\right)$ & Density $\left(\mathbf{k g} \cdot \mathbf{m}^{-\mathbf{3}}\right)$ & Pour point $\left({ }^{\circ} \mathbf{C}\right)$ \\
\hline Madit M7 ADS III & SAE 20W-40 & API CF/SF & 127.4 & 899 & -30 \\
\hline
\end{tabular}

Table 2 Performance of sampling of oil samples

\begin{tabular}{|l||c|c|c|c|c|c|c|c|}
\hline Sampling date & $\mathbf{9 . 4 . 2 0 1 6}$ & $\mathbf{1 1 . 4 . 2 0 1 6}$ & $\mathbf{3 . 5 . 2 0 1 6}$ & $\mathbf{2 4 . 5 . 2 0 1 6}$ & $\mathbf{6 . 6 . 2 0 1 6}$ & $\mathbf{2 . 7 . 2 0 1 6}$ & $\mathbf{2 4 . 9 . 2 0 1 6}$ & $\mathbf{2 4 . 1 0 . 2 0 1 6}$ \\
\hline Meter status (Eh) & 870 & 875 & 923 & 979 & 1,024 & 1,075 & 1,125 & 1,170 \\
\hline Sampling interval (Eh) & 0 & 5 & 48 & 56 & 45 & 51 & 50 & 45 \\
\hline Count per cartridge (Eh) & 0 & 5 & 53 & 109 & 154 & 205 & 255 & 300 \\
\hline
\end{tabular}

Table 3 Measured content of major structural metals in oil

\begin{tabular}{|l|c|c|c|c|c|c|c|c|}
\hline Sampling date & $\mathbf{9 . 4 . 2 0 1 6}$ & $\mathbf{1 1 . 4 . 2 0 1 6}$ & $\mathbf{3 . 5 . 2 0 1 6}$ & $\mathbf{2 4 . 5 . 2 0 1 6}$ & $\mathbf{6 . 6 . 2 0 1 6}$ & $\mathbf{2 . 7 . 2 0 1 6}$ & $\mathbf{2 4 . 9 . 2 0 1 6} \mathbf{2 4 . 1 0 . 2 0 1 6}$ \\
\hline Eh count per cartridge (Eh) & 0 & 5 & 53 & 109 & 154 & 205 & 255 & 300 \\
\hline Al (ppm) & 1.41 & 0.68 & 3.23 & 6.91 & 5.59 & 8.49 & 10.78 & 11.23 \\
\hline Cr (ppm) & 0 & 0 & 0.11 & 0.37 & 0.53 & 1.16 & 1.38 & 1.62 \\
\hline Cu (ppm) & 0.31 & 0.53 & 1.43 & 2.6 & 2.43 & 3.88 & 4.25 & 4.62 \\
\hline Fe (ppm) & 0 & 10.48 & 15.79 & 23.8 & 30.25 & 56.29 & 73.47 & 98.93 \\
\hline
\end{tabular}

default values. All information on these samples is provided in Table 3.

A sample of the oil taken must constitute the average composition of the lubricant used in the machine. It was taken at the engine's operating temperature (minimum oil temperature of $65^{\circ} \mathrm{C}$ ), 3 minutes after stopping the engine at the latest. Sampling was performed using a sampling preparation from an oil tank at $2 / 3$ of its height through a hole for inspection gauge. Oil suction was carried out by means of a plastic suction syringe with an extension adjusted to the needed length. Samplings taken were filled to new plastic sample containers with volume of $50 \mathrm{ml}$ and were filled up to $80 \%$ of container volume. There were performed 8 oil takings; $200 \mathrm{ml}$ of engine oil was sucked in each taking. To avoid unwanted contamination and impurities, a new sucking device, previously unused, was used only for sampling from the investigated machine. Samples taken were held in new, dry and clean sample containers that were carefully closed after the sampling. Sample containers were marked and basic data were recorded on them (sampling number, sampling date, operating hours counter status) after taking a sample. The first sampling was performed after engine oil replacement and a short machine operation. Other samples were taken at intervals of 50 hours of operation. However, this interval has not been strictly maintained because the observed tractor was not always at the place suitable for engine oil sampling at the exact time. Seven samples were taken from the tractor oil tank and 1 sampling of new oil in order to compare the measured parameters (Čupera et al., 2010).

Three measuring instruments were used in order to find out the state of the engine oil. Chemical composition of the oils was determined by means of a Spectroil Q100 instrument. In addition to this, Mettler Toledo Densito 30 PX digital density was used for determination of oil density and Anton Paar DV-3P rotational viscometer was used for determination of oil dynamic viscosity.

Oil chemical composition was determined by means of a Spectroil Q100 instrument (a complete semiconductor spectrometer designed for oil sample analysis). This device measures the trace contents of elements dissolved or deposited as fine particles in petroleum minerals or hydraulic mixtures using a long-term proven and reliable rotating disc electrode technique (Kumbár et al., 2012). It meets the requirements of the ASTM D6595 standard method for determination of wear of metals and contaminants used in lubricating oils or hydraulic mixtures (Mettler Toledo.CZ, 2014, Spectro.CZ, 2014).

Density was measured using a portable digital meter Mettler Toledo Densito 30 PX. This device is equipped with a special scale for measuring of petroleum products. It allows determination of sample density in a short time. It uses the oscillating tube method combined with accurate temperature measurement (Ilabo.CZ, 2014).

Anton Paar DV-3P rotational viscometer was used to measure the viscosity. It measures the torque of the rotating swindle immersed in sample. It works on the principle of measuring torsion necessary to overcome the resistance of a rotating cylinder or disc immersed in the measured material. Rotating cylinder or spindle are connected through a spring to a motor shaft rotating at a defined speed. Shaft rotation angle was measured electronically, providing accurate information on shaft or spindle position. Dynamic viscosity value ( $\mathrm{mPa} \cdot \mathrm{s}$ ) was displayed on the basis of internal calculation from measured values.

\section{Results and discussion}

Substances determined in oil were divided into two groups. The first group involves metals that form the main engine 


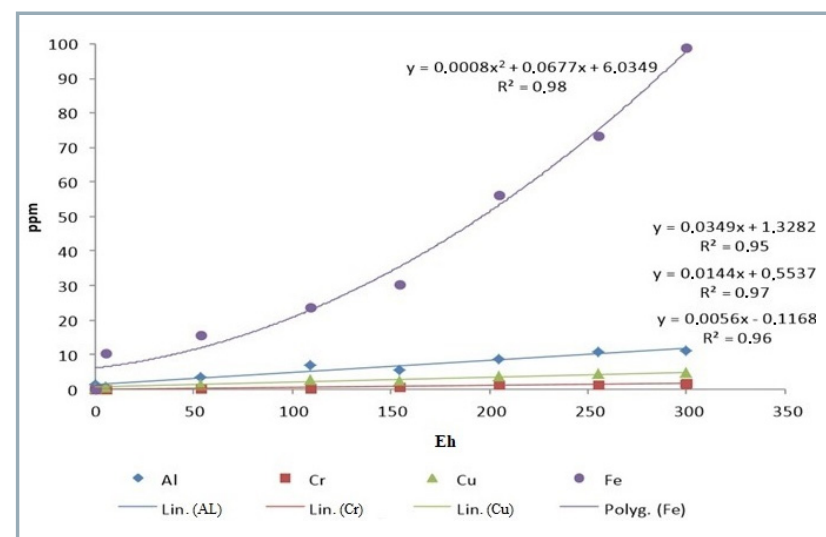

Fig. 1 Increasing metal content in engine oil

constructional parts and the second group includes less important metals. The following tables show the measured values of the amount of main construction metals. Content of individual elements is indicated in ppm.

Considering the Fig. 1, it is obvious that the main construction metal, i.e. Fe is the most present in the samples taken. In comparison to other metals, Fe content in oil is the highest and increase in Fe content is the steepest and most distinct. It can be said that its content grows gradually in case of oil used up to 150 hours of operation. Fe content has almost doubled in the following sample and there was a more distinct increase in the other two samplings. This result may indicate that engine is already more worn and excessive abrasion takes place. Other monitored metals included Al, $\mathrm{Cu}$ and $\mathrm{Cr}$. Content of these metals in the samples taken was smaller in comparison to Fe content. In regards to these other metals, Al content was mostly prominent in oil; this is most likely because it is used in larger amounts in engines in comparison with the remaining two. Continuous increase in content of these three metals is gradual and obvious.

The other metals determined in the oil include $\mathrm{Mg}, \mathrm{Mn}$, $\mathrm{Na}$ and $\mathrm{Ni}$, as well as $\mathrm{Si}$, which, however, is not a construction metal, yet it can be determined in oil analysis. These substances were already contained in a certain amount in the new oil due to additives. As the duration of the tractor

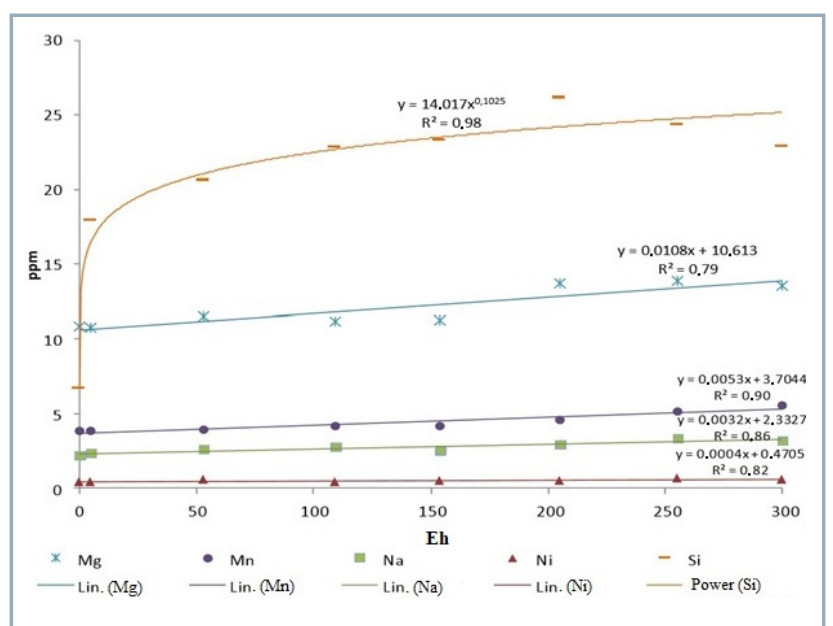

Fig. 2 Content of other metals in oil

operation increased, their content also slightly increased. In regards to this group, Si content was the most prominent in oil. Measured values of individual metals were modelled according to the basic math functions - linear, polynomic (quadratic) and power. Due to these correlations, R2 determination coefficient, value of which determines the suitability of used function, was monitored. Since this coefficient ranged from 0.79 to 0.98 , it can be stated that the functions types have been selected accurately (Černý, 2009; Severa et al., 2009). A significant indicator, which can signalise oil depreciation, is density. Density changes due to the operation. Increased lubricant density and its nonconsistency impair the quality of lubrication and increase the energy losses due to overcoming of lubricant resistance. Changes in density indicated that oil has been polluted by other substances (Černý, 2007; Oleje.cz, 2014).

Density values gradually increased in the investigated oil. This phenomenon was mainly due to the amount of abrasive particles in oil. Density is affected not only by abrasive metals, but also by other impurities that occur during the operation or they get to the oil from external environment. Therefore, when evaluating the oil state, it is necessary to

Table 4 Measured amount of other metals found in oil

\begin{tabular}{|l||c|c|c|c|c|c|c|c|}
\hline Date of sampling & $\mathbf{9 . 4 . 2 0 1 6}$ & $\mathbf{1 1 . 4 . 2 0 1 6}$ & $\mathbf{3 . 5 . 2 0 1 6}$ & $\mathbf{2 4 . 5 . 2 0 1 6}$ & $\mathbf{6 . 6 . 2 0 1 6}$ & $\mathbf{2 . 7 . 2 0 1 6}$ & $\mathbf{2 4 . 9 . 2 0 1 6} \mathbf{2 4 . 1 0 . 2 0 1 6}$ \\
\hline Eh count per cartridge (Eh) & 0 & 5 & 53 & 109 & 154 & 205 & 255 & 300 \\
\hline $\mathbf{M g}$ (ppm) & 10.83 & 10.73 & 11.51 & 11.18 & 11.23 & 13.7 & 13.87 & 13.53 \\
\hline $\mathbf{M n}$ (ppm) & 3.89 & 3.83 & 3.97 & 4.18 & 4.17 & 4.62 & 5.14 & 5.54 \\
\hline $\mathbf{N a}(\mathbf{p p m})$ & 2.25 & 2.41 & 2.6 & 2.76 & 2.56 & 2.93 & 3.34 & 3.23 \\
\hline $\mathbf{N i}(\mathbf{p p m})$ & 0.46 & 0.47 & 0.57 & 0.43 & 0.55 & 0.48 & 0.67 & 0.56 \\
\hline $\mathbf{S i}$ (ppm) & 6.73 & 17.92 & 20.61 & 22.84 & 23.28 & 26.12 & 24.37 & 22.92 \\
\hline
\end{tabular}

Table 5 Measured oil density

\begin{tabular}{|l||c|c|c|c|c|c|c|c|}
\hline Date of sampling & $\mathbf{9 . 4 . 2 0 1 6}$ & $\mathbf{1 1 . 4 . 2 0 1 6}$ & $\mathbf{3 . 5 . 2 0 1 6}$ & $\mathbf{2 4 . 5 . 2 0 1 6}$ & $\mathbf{6 . 6 . 2 0 1 6}$ & $\mathbf{2 . 7 . 2 0 1 6}$ & $\mathbf{2 4 . 9 . 2 0 1 6} 24.10 .2016$ \\
\hline Eh count per cartridge (Eh) & 0 & 5 & 53 & 109 & 154 & 205 & 255 & 300 \\
\hline Density $\left(\mathbf{k g} \cdot \mathbf{m}^{-\mathbf{3}}\right)$ & 0.8771 & 0.8782 & 0.8782 & 0.8793 & 0.8798 & 0.8809 & 0.8815 & 0.8826 \\
\hline
\end{tabular}




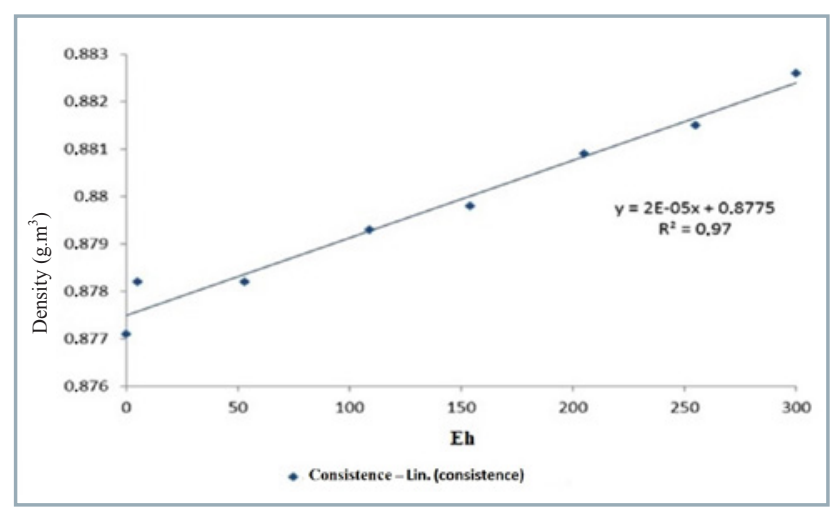

Fig. 3 Measured density values

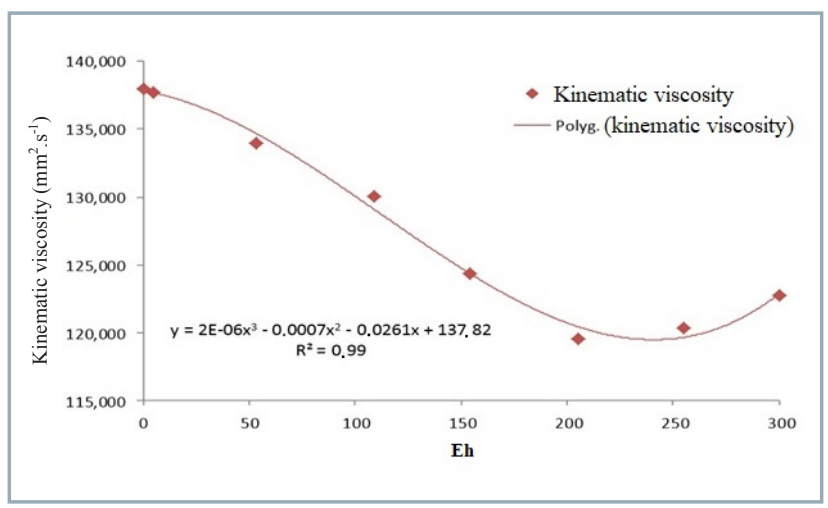

Fig. 4 Dependence of kinematic viscosity on time

Table 6 Breakdown of dynamic viscosity, density and kinematic viscosity

\begin{tabular}{|c|c|c|c|c|c|c|c|c|}
\hline Sampling date & 9.4. 2016 & 11.4.2016 & 3.5.2016 & 24.5. 2016 & 6.6 .2016 & 2.7.2016 & 24.9. 2016 & 24. 10. 2016 \\
\hline Eh count per cartridge (Eh) & 0 & 5 & 53 & 109 & 154 & 205 & 255 & 300 \\
\hline Dynamic viscosity (mPa.s) & 121.018 & 120.944 & 117.638 & 114.348 & 109.403 & 105.294 & 106.103 & 108.295 \\
\hline Density $\left(\mathrm{g} \cdot \mathrm{cm}^{3}\right)$ & 0.8771 & 0.8782 & 0.8782 & 0.8793 & 0.8798 & 0.8809 & 0.8815 & 0.8826 \\
\hline Kinematic viscosity & 137.975 & 137.717 & 133.954 & 130.045 & 124.350 & 119.350 & 120.366 & 122.700 \\
\hline
\end{tabular}

pay attention also to this measured quantity, since measured density is used also in calculation of dynamic viscosity and thus directly affects resulting viscosity. Increasing nature of density can be clearly seen in Fig. 4. The first samples taken from the tractor oil tank show almost identical density there was a slight increase in density in comparison with new oil. Therefore, it can be said that no changes in density occurred in the first quarter of the recommended service interval. Subsequently, density showed increasing trends due to presence of abrasive metals that had just occurred their content increase more distinctly after 100 hours of operation. Linear function was fitted to the measured values of individual oil samples. The R2 determinant coefficient reached a value of up to 0.97 and thus can be stated that function type was selected appropriately (Kučera and Rousek, 2008; Kumbár et al., 2012; Tulík et al., 2014). Density and dynamic viscosity were measured in tested samples in order to determine the kinematic viscosity. It is one of the essential indicators determining the engine oil state. During trouble-free operation of lubricant in machine, viscosity increases by thickening the oil with impurities and oxidation products; it decreases in the opposite case, e.g. by contamination of lubrication system by fuel or other diluting substances.

In the case of tested oil, kinematic viscosity was gradually decreasing at first as shown in Fig. 4. This phenomenon can be explained especially by mechanic and thermal stresses to which the oil is exposed during operation. Oil degrades due to this reason, i.e. base oil loses its properties, as well as additives represented in oil decrease. If viscosity is too low, mixed to dry friction can occur, resulting in heavy wear and tear, even in engine failure in extreme cases. The lowest viscosity was observed in a sample taken after 200 hours of operation. This corresponds to the normal state when viscosity decreases because of operation. Fig. 4 shows that viscosity has started to increase again in the last two samples taken. This is especially caused by exceeding of recommended replacement interval, when oil is thickened by impurities and abrasive metals. During the operation, oil viscosity should not change by more than $\pm 20 \%$. This requirement has been met and difference between the highest and lowest viscosity amounted to $13.4 \%$. Polynomic (cubic) function was fitted to the kinematic viscosity values of particular oil samples. The R2 determination coefficient reached the value of 0.99 here, thus it can be stated that this function type was selected very appropriately.

\section{Conclusions}

On the basis of described measurements, it is possible to state that density values of tested oil in the observed tractor vehicle showed evident increasing trend. This condition was a clear consequence of the increasing amount of abrasive particles in oil.

Kinematic viscosity of oil was gradually decreasing. This was mainly caused by thermal and mechanical stresses to which the oil in engine was exposed to.

After 200 Eh, kinematic viscosity increased due to the increased amount of impurities and abrasive metals in oil. Considering all the measured values, it is highly recommendable that recommended oil change interval should be strictly preserved. This is in compliance with findings published by Sejkorová and Glos (2017), who experimentally observed that it is not advisable to extend change intervals in Zetor tractors. In particular, a number of abrasive metals is already present in oil after 200 Eh, resulting in increased density and also viscosity. Therefore, oil lacks its lubricating properties in comparison to new oil. In such case, it is unnecessary to continuously examine the engine oil state for prolongation service intervals. Observation of these parameters would only make sense merely to determine the engine state, i.e. whether it works properly or shows failures. 
On the basis of data found, it is possible to state that continuous engine oil monitoring is not required within one service interval. It should be observed whether the engine operates properly or it has been damaged due to normal degradation and wear of engine oil at service intervals. Tracking of parameters is particularly important in a large fleet, in which oil analysis can be a significant tool for reduction of running costs and prolongation of engine lives. This paper observes a significant problematic in the area of engine oils, bringing new knowledge that can be followed up, if research continues in this field.

\section{Acknowledgement}

The research has been supported by the project TP 6/2017: Defectoscopic quality assessment of technical and organic materials; financed by IGA AF MENDELU.

\section{References}

ČERNÝ, J. 2007. Engine oil properties - Detergents and dispersants. [on-line), [cit. 2016-2-12]. Available at: <http://www.oleje.cz/ clanek/Vlastnosti-motorovych-oleju-Detergenty-a-disperzanty> (In Czech: Vlastnosti motorových olejů - Detergenty a disperzanty). ČERNÝ, J. 2009. [on-line], [cit. 2016-2-11]. When it says: base oil. Engine oil properties. Available at: <https://www.oleje.cz/ clanek/Kdyz-se-rekne-zakladove-oleje> (In Czech: Když se řekne: základové oleje. Vlastnosti motorových olejů).

ČUPERA, J. - SEDLÁK, P. - KARAFIÁT, P. 2010. Differences in rheological profile of diesel and biodiesel fuel. In Acta Universitatis Agriculturae et Silviculturae Mendelianae Brunensis, vol. 68, no. 5, pp. 67-74.

HROMÁDKO, J. 2011. Internal Combustion Engines: A Comprehensive Overview of Issues for All Types of Automotive Schools. $1^{\text {st }}$ ed. Prague: Grada, 2011, 296 pp. ISBN 978-80-24734750. (In Czech: Spalovací motory: Komplexní přehled problematiky pro všechny typy technických automobilních škol).

ILABO.CZ. 2014. Densito 30PX. [on-line], [cit. 2016-24-03]. Available at: <http://www.ilabo.cz/produkty/laboratorni-pristroje-opticke/ mereni-hustoty/densito-30px/>

KOSIBA, J. - ČORNÁK, Š. - GLOS, J. - JABLONICKÝ, J. - VOZÁROVÁ, V. PETROVIČ, A. - CSILLAG, J. 2016. Monitoring oil degradation during operating test. In Agronomy Research, vol. 14, no. 5, pp. 1626-1634.
KUČERA, M. - ROUSEK, M. 2008. Evaluation of thermooxidation stability of biodegradable recycled rapeseed-based oil NAPRO-HO. In Research in Agricultural Engineering, vol. 54, no. 4, pp. 163-169. KUČERA, M. - ALEŠ, Z. 2017. Morphology analysis of friction particles generated in tractor transmission oils. In Acta Technologica Agriculturae, vol. 20, no. 3, pp. 57-62.

KUMBÁR, V. - DOSTÁL, P. - ČUPERA, J. - SABALIAUSKAS, A. 2012. Kinematic viscosity of four-stroke engine oils. In Journal of Young Scientists = Jaunuju Mokslininku Darbai, vol. 36, no. 3, pp. 134-139. METTLER TOLEDO.CZ. 2014. Densito 30PX. [on-line], [cit. 201624-03]. Available at: <http://cs.mt.com/cz/cs/home/products/ Laboratory_Analytics_Browse/Density_Family_Browse_main/ Portable_density_meter_family_browse_main/Densito_30PX. html>

OLEJE.CZ. 2014. Lubricant additives. [on-line], [cit. 2016-2-25]. Available at: http://www.oleje.cz/clanek/Aditiva_do_maziv (In Czech: Aditiva do maziv).

SEVERA, L. - HAVLIIČEK, M. - KUMBÁR, V. 2009. Temperature dependent kinematic viscosity of different types of engine oils. In Acta Universitatis Agriculturae et Silviculturae Mendelianae Brunensis. vol. 57, no. 4, pp. 95-102.

SEJKOROVÁ, M. - GLOS, J. J. 2017. Analysis of degradation of motor oils used in Zetor tractors. In Acta Universitatis Agriculturae et Silviculture Mendelianae Brunensis, vol. 65, no. 1, pp. 179-187.

SPECTRO.CZ. 2014. Spectroil Q100 - Spectrometer for oil analysis. [on-line], [cit. 2016-24-03]. Available at: <http://www.spectro. cz/store/spectroil-q100-cz.pdf> (In Czech: Spectroil Q100 Spektometr pro analýzu olejů).

TKÁČ, Z. - ČORŇÁK, Š. - CVIKLOVIČ, V. - KOSIBA, J. - GLOS, J. JABLONICKÝ, J. - BERNÁT, R. 2017. Research of biodegradable fluid impacts on operation of tractor hydraulic system. In Acta Technologica Agriculturae, vol. 20, no. 2, pp. 42-45.

TULÍK, J. - HUJO, L. - STANČíK, B. - ŠEVČíK, P. 2013. Research of new ecological oil-based fluid. In Journal of Central European Agriculture, vol. 14, no. 4, pp. 1384-1393.

TULÍK, J. - KOSIBA, J. - STANČÍK, B. - ŠTULAJTER, I. 2014. Pollution analysis of new synthetic biodegradable fluid during durability test of hydrostatic pumps. In Acta Technologica Agriculturae, vol. 17, no. 1 , pp. 24-28. 